\title{
RELASI GENDER, TEKANAN EKONOMI, MANAJEMEN KEUANGAN, STRATEGI NAFKAH, DAN KUALITAS HIDUP PADA KELUARGA NELAYAN
}

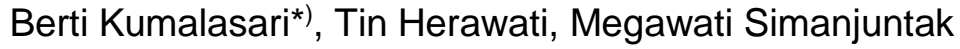 \\ Departemen IImu Keluarga dan Konsumen, Fakultas Ekologi Manusia, Institut Pertanian Bogor, \\ Bogor 16680, Indonesia
}

*)Email: bertikumalasariikk50@gmail.com

\begin{abstract}
Abstrak
Tingginya biaya hidup di berbagai aspek menjadi tantangan yang harus dihadapi keluarga saat ini sehingga keluarga harus memiliki strategi dalam pengelolaan sumber daya untuk mencegah timbulnya konflik dan tekanan ekonomi pada keluarga, khususnya keluarga nelayan yang sumber nafkahnya sangat tergantung dengan alam. Penelitian ini bertujuan untuk menganalisis pengaruh relasi gender, tekanan ekonomi, manajemen keuangan dan strategi nafkah terhadap kualitas hidup keluarga nelayan. Penelitian ini menggunakan desain kuantitatif. Lokasi penelitian yaitu Desa Mayangan, Kecamatan Legon Kulon, Kabupaten Subang, Jawa Barat yang dipilih berdasarkan mata pencarian pendudukan dominan nelayan. Responden pada penelitian ini adalah istri nelayan dan berjumlah 60 istri nelayan. Responden dipilih dengan teknik pengambilan contoh acak sederhana. Data primer dikumpulkan secara langsung menggunakan teknik wawancara kepada istri dengan bantuan kuesioner terstruktur. Pengolahan data menggunakan analisis data SEM PLS. Hasil menunjukkan bahwa tekanan ekonomi berpengaruh nyata terhadap manajemen keuangan, strategi nafkah berpengaruh nyata terhadap manajemen keuangan, relasi gender berpengaruh nyata terhadap strategi nafkah, dan tekanan ekonomi berpengaruh nyata terhadap kualitas hidup. Implikasi penelitian ini adalah pemerintah sebaiknya memberikan pendampingan kepada istri berupa kiat-kiat dalam mengatasi tekanan ekonomi sehingga perlu dilakukan penyuluhan tentang pentingnya relasi gender, manajemen keuangan, dan strategi nafkah untuk mengatasi permasalahan keluarga.
\end{abstract}

Kata kunci: kualitas hidup, manajemen keuangan, relasi gender, strategi nafkah, tekanan ekonomi

\section{Gender Relations, Economic Pressures, Financial Management, Livelihood Strategies, and Quality of Life among Fishermen Families}

\begin{abstract}
The high cost of living in various aspects becomes a challenge that must be faced by the family today, so that family must have a strategy in the management of resources to prevent the occurrence conflict and trigger economic pressure on the family, especially among fishermen families. This study aimed to determine the effect of gender relations, economic pressures, financial management and livelihood strategies on the quality of life of fishermen families. This research used quantitative study design. The research location was Mayangan Village, Legon Kulon Subdistrict, Subang Regency, West Java. The place of this study was selected based on the livelihood of the dominant fisherman population, is Mayangan Village. Respondents in this research were fisherman's wife and willing to be the respondent. The respondents were 60 fishermen's wives. Respondents were selected by using simple random sampling technique. Primary data were collected directly using interview techniques using structured questionnaires. The results showed that economic pressure and financial management influence significantly toward quality of life, financial management and gender relations influence significantly toward livelihood strategy. The implication of this research is the government should provide assistance to the wife in the form of tips in overcoming the economic pressure, so it is necessary to develop family empowerment program with issues in gender relation, financial management and livelihood strategy to solve family problems.
\end{abstract}

Keywords: economic pressure, financial management, gender relations, livelihood strategies, quality of life

\section{PENDAHULUAN}

Indonesia merupakan negara kepulauan yang memiliki kekayaan alam yang berlimpah. Sumber daya perikanan merupakan salah satu kekayaan Indonesia sebagai sumber pendapatan nelayan. Menurut UU Nomor 45
Tahun 2009, nelayan didefinisikan sebagai orang yang mata pencahariannya melakukan penangkapan ikan. Hasil penelitian Satria et al. (2015) menunjukkan masih banyaknya usaha nelayan dengan menggunakan teknologi penangkapan yang masih bersifat tradisional dan skala kecil dan hanya sedikit yang 
mengakses lembaga perbankan dan nonbank sebagai modal usaha $(0,0-5,5 \%)$, dan mayoritas hasil tangkapan dijual di dalam kabupaten/kota $(>90,0 \%)$ kepada pedagang (50,0-70\%). Tingkat pendidikan nelayan masih sangat rendah yaitu tidak tamat SD $(27,0-$ $32,0 \%)$ dan tamat SD $(43,0-50,0 \%)$ dan ratarata pendapatan rumah tangga yang paling besar adalah Rp3.030.200,00/bulan.

Saat ini, semakin meningkatnya biaya hidup di berbagai aspek menjadi tantangan yang harus dihadapi keluarga menyebabkan keluarga harus memiliki strategi dalam pengelolaan sumber daya agar tidak menimbulkan konflik dan pemicu tekanan ekonomi pada keluarga (Rodhiyah, 2012). Permasalahan lain yang dihadapi oleh keluarga nelayan adalah menurunnya volume ikan yang ditangkap karena jumlah nelayan yang meningkat, ketergantungan pada musim, tercemarnya wilayah tangkapan, ketidakadilan harga, lemahnya teknologi dan modal, terbatasnya SDM, terbatasnya akses sumber daya, serta lemahnya organisasi (Satria, 2009). Secara sosiologis, keluarga nelayan menghadapi sumber daya yang bersifat open access, yang menyebabkan nelayan harus berpindah-pindah untuk memperoleh hasil maksimal dengan ketidakpastian dan risiko yang tinggi.

Berdasarkan data kemiskinan BPS (2013) menunjukkan bahwa 23,79 persen rumah tangga nelayan tergolong miskin, dengan tingkat kesejahteraan rendah lebih dari 10 persen (Satria et al., 2015). Faktor-faktor yang memengaruhi kemiskinan pada keluarga ialah pendidikan yang rendah, kesulitan mendapatkan pekerjaan lain, pendapatan yang sangat rendah, minimnya modal, dan lemahnya penguasaan aspek manajemen dan teknologi (Husin, 2009; Soesilo, 2007). Pendapatan nelayan sangat bergantung pada jenis armada yang digunakan. Semakin besar dan modern armada yang digunakan berpeluang untuk memperoleh hasil tangkapan semakin banyak, sehingga dapat meningkatkan pendapatan yang berpeluang meningkatkan kesejahteraan (Sabarella et al., 2014; Satria et al., 2015).

Rendahnya tingkat kesejahteraan yang juga ditunjukkan dengan kemiskinan menunjukkan ketidakmampuan keluarga dalam merespon dan beradaptasi dengan lingkungan, yang selanjutnya dapat menyebabkan keluarga mengalami tekanan ekonomi (Sunarti et al., 2013). Tekanan ekonomi adalah ketidakmampuan keuangan yang dirasakan oleh keluarga sehingga menggangu pemenuhan kebutuhan, meningkatkan stres, dan menurunkan kualitas hidup (Robila \& Krishnakumar, 2005). Tekanan ekonomi akan mendorong keluarga untuk mengoptimalkan manajemen keuangan dan stategi nafkah sehingga keluarga dapat bertahan untuk menjaga kelangsungan dan keberlanjutan kehidupan (Sunarti et al., 2005; Fofana, 2009). Hal ini dilakukan agar pendapatan tidak habis begitu saja dan dapat digunakan saat dibutuhkan.

Selain itu, dibutuhkan strategi nafkah ganda untuk memelihara dan meningkatkan aset, sumber daya, dan kemampuannya untuk generasi selanjutnya, sebagai upaya meningkatkan kualitas hidup keluarga (Okech, 2012; Rodhiyah, 2012). Namun, tidak semua keluarga mampu melakukan manajemen keuangan dengan baik karena menganggap tidak perlu melakukan dengan asumsi setiap bulan pengeluaran sama atau pendapatan yang diterima tidak menentu. Minat yang mendorong istri melakukan manajemen keuangan keluarga dipengaruhi oleh faktor pendidikan, kepribadian, pendapatan, dan pola pikir (Iskandar, 2008; Firdaus \&Sunarti, 2009). Hasil penelitian Yohnson (2004) menyatakan keluarga dengan ekonomi rendah, memiliki latar belakang pendidikan yang rendah sehingga memiliki kesulitan untuk membuat perencanaan keuangan. Praktik strategi nafkah membutuhkan modal keluarga sehingga modal keluarga yang rendah seperti pendidikan rendah, tidak memiliki keterampilan, sumber daya alam terbatas dan interaksi dengan masyarakat rendah akan menyulitkan keluarga dalam upaya pemenuhan kebutuhan hidup (Widodo, 2011). Keluarga yang tidak dapat memenuhi kebutuhan hidupnya menunjukkan tingkat kesejahteraan yang rendah (Theofilou, 2013).

Kesejahteraan keluarga nelayan yang belum tercapai mendorong dan menuntut keluarga tidak hanya suami yang bekerja namun istri juga bekerja. Istri yang awalnya hanya bekerja di sektor domestik (melayani suami, mengurus rumah tangga, dan merawat anak) harus membantu suami bekerja di sektor publik. Namun, hingga saat ini peran kontribusi perempuan di sektor pertanian terhadap kesejahteraan keluarga kurang diperhitungkan (Irzalinda, Puspitawati, \& Muflikhati, 2014). Masyarakat dengan budaya patriarki menempatkan laki-laki sebagai pencari nafkah dan perempuan bertugas mengurus rumah tangga. Salah satu strategi keluarga miskin dalam menghadapi kondisi krisis dengan cara melakukan alokasi sumber daya yang optimal, 
salah satunya dengan manajemen keuangan, khususnya pada tenaga kerja di dua sektor, yaitu sektor publik dan domestik (Kusumo, Sunarti, \& Pranadji, 2009; Durband, Britt, \& Grable, 2010). Keterlibatan dan kontribusi istri sebagai pelaku usaha atau pencari nafkah, dapat mengurangi kerja sama antara suami dan istri dalam berbagai aktivitas, baik peran dalam sektor domestik maupun sosial kemasyarakatan sehingga dibutuhkan pembagian peran antara suami-istri yang seimbang untuk mencapai kesejahteraan keluarga (Puspitawati, 2012). Relasi gender berpengaruh terhadap manajemen keuangan dan strategi nafkah yang dapat meningkatkan kualitas hidup keluarga (Pupitawati, 2012).

Beberapa penelitian sebelumnya mengkaji tentang kualitas hidup secara umum dan berdasarkan aspek sosial-ekonomi (Puspitawati, 2009; Simanjuntak, Puspitawati, \& Djamaludin, 2010; Muflikhati et al., 2010; Mudey et al., 2011), kualitas hidup di negara berkembang (Khizindar, 2009), dan juga kualitas hidup lansia (Netuveli \& Blane, 2008). Kualitas hidup didefinisikan sebagai seberapa jauh rasa kebahagiaan atau kesejahteraan dan kepuasan yang dialami (Park \& Shin, 2005). Kualitas hidup sering digambarkan dengan dimensi kualitas hidup subjektif dan kualitas hidup objektif (Netuveli \& Blane, 2008). Penelitian sebelumnya menunjukkan bahwa relasi gender berpengaruh terhadap kualitas hidup (Simanjuntak, Puspitawati, \& Djamaludin, 2010), tekanan ekonomi berpengaruh terhadap kualitas hidup (Firdaus \& Sunarti, 2009), manajemen keuangan berpengaruh terhadap kualitas hidup (Grable, Park, \& Joo,2009), dan juga strategi nafkah berpengaruh terhadap kualitas hidup (Dharmawan, 2007). Penelitian ini berbeda dari penelitian sebelumnya dengan memfokuskan pada keluarga nelayan dan melihat kualitas hidup berdasarkan objektif dan subjektif. Oleh karena itu, penelitian ini bertujuan untuk mengidentifikasi relasi gender, tekanan ekonomi, manajemen keuangan keluarga, strategi nafkah dan kualitas hidup pada keluarga keluarga nelayan dan menganalisis pengaruh relasi gender, tekanan ekonomi, manajemen keuangan keluarga, dan strategi nafkah terhadap kualitas hidup pada keluarga keluarga nelayan.

\section{METODE}

Desain penelitian ini menggunakan quantitative study dengan lokasi penelitian dipilih secara purposive, yaitu di Desa Mayangan, Kecamatan Legonkulon,
Kabupaten Subang, Jawa Barat. Pemilihan tempat berdasarkan mata pencarian penduduk yang dominan nelayan. Populasi penelitian ini adalah seluruh keluarga nelayan yang bertempat tinggal di Desa Mayangan berjumlah 110 orang, dengan responden istri dari keluarga nelayan. Jumlah contoh yang diambil untuk penelitian ini sebanyak 60 orang istri dari keluarga nelayan. Teknik penarikan contoh yang digunakan adalah acak sederhana (simple random sampling).

Data primer dikumpulkan secara langsung menggunakan teknik wawancara kepada istri dengan bantuan kuesioner terstruktur. Karakteristik keluarga contoh (usia, lama menikah, lama pendidikan, pendapatan, jumlah anggota keluarga, dan pengeluaran), skala data yang digunakan pada karakteristik keluarga adalah rasio. Kuesioner relasi gender dimodifikasi dariKrzaklewska (2014) dan Puspitawati (2012); terdiri atas tiga dimensi yaitu domestik, publik, dan sosial kemasyarakatan berjumlah 28 ipernyataan dengan nilai Cronbach's alpha 0,900. Kuesioner diukur menggunakan skala Likert (1-6), yaitu 1 = Suami saja; 2 = Suami dominan; 3 = Suami dan istri setara; 4 = Istri dominan; 5 = Istri saja; 6 = Lainnya. Kuesioner tekanan ekonomi objektif diacu dan dimodifikasi dari Indikator Kemiskinan BPS, berjumlah 14 pernyataan dengan nilai Cronbach's alpha 0,813. Kuesioner diukur menggunakan skala $0-1$, yaitu $0=$ tidak; $1=y a$. Kuesioner tekanan ekonomi subjektif diacu dan dimodifikasi dari Hilton dan Devall (1997), berjumlah 15 pernyataan dengan nilai Cronbach's alpha 0,966. Kuesioner diukur menggunakan skala Likert (1-4), yaitu 1=tidak pernah; $2=$ pernah; 3 =sering; $4=$ selalu. Kuesioner manajemen keuangan diacu dan dimodifikasi dari Fitzsimmons et al. (1993); Firdaus dan Sunarti (2009); Kumari (2011), terdiri dari tiga dimensi yaitu perencanaan, pelaksaan, dan evaluasi keuangan, berjumlah 20 pernyataan dengan nilai Cronbach's alpha 0,873 . Kuesioner diukur menggunakan skala Likert (1-4), yaitu 1=tidak pernah; 2=pernah; $3=$ sering; $4=$ selalu. Kuesioner strategi nafkah mengacu pada konsep Scoones (1998), berjumlah 14 pernyataan dengan nilai Cronbach's alpha 0,616. Kuesioner diukur menggunakan skala Likert (1-4), yaitu 1=tidak pernah; 2=pernah; 3=sering; 4=selalu. Kuesioner kualitas hidup objektif diukur dengan pendekatan Lawton (2001) berjumlah 30 item pernyataan dengan nilai Cronbach's alpha 0,883. Kuesioner kualitas hidup objektif diukur menggunakan skala $0-1$, yaitu $0=$ tidak; $1=y a$. Kuesioner kualitas hidup subjektif 
dimodifikasi dari Puspitawati (2012); Zuliany (2013), berjumlah 28 pernyataan dengan nilai Cronbach's alpha 0,883. Kuesioner kualitas hidup subjektif diukur menggunakan skala Likert (1-4), yaitu 1=sangat tidak puas; $2=$ tidak puas; $3=$ puas; $4=$ sangat puas .

Variabel selanjutnya diberikan skor penilaian pada setiap pertanyaan kuesioner. Setelah itu, skor total dari masing-masing variabel ditransformasikan menjadi indeks untuk menyamakan satuan agar perbandingan pengategorian data setiap variabel seragam. Pengategorian rendah, sedang, dan tinggi dikategorikan berdasarkan cut off pengategorian oleh Sunarti et al. (2005) yaitu $(00,0-60,0)$ dikategorikan rendah, $(60,0-79,0)$ dikategorikan sedang, dan $(80,0-100,0)$ dikategorikan tinggi.

Data yang dikumpulkan melalui wawancara, kemudian diolah dan dianalisis melalui Microsoft Excel dan SPSS for windows. Proses pengolahan data meliputi editing, coding, entry, scoring, dan analyzing. Pengolahan data dilakukan dengan menggunakan analisis deskriptif dan analisis inferensia. Analisis deskriptif (rata-rata, nilai minimum, nilai maksimum, dan persentase) untuk mengidentifikasi karakteristik keluarga nelayan, relasi gender, tekanan ekonomi, manajemen keuangan keluarga, strategi nafkah dan kualitas hidup.).

Analisis dengan SEM PLS dilakukan untuk menganalisis pengaruh variabel relasi gender, tekanan ekonomi, manajemen keuangan keluarga, strategi nafkah terhadap kualitas hidup pada keluarga nelayan. PLS dikembangkan sebagai metode umum untuk melakukan pendugaan model struktural yang diukur secara tidak langsung oleh peubah menifes. PLS merupakan metode lunak karena tidak memerlukan asumsi sebaran dari peubah pengamatan dan ukuran tidak harus besar (Chin, 2000). Data yang digunakan dalam pengujian PLS yaitu menggunakan data hasil rata-rata skor pernyataan dari setiap dimensi (Latan, 2013). Beberapa langkah berikut ini dilakukan untuk membuat model yang lengkap dalam pengolahan data, yaitu: 1) pengembangan model berbasis teori; 2) pengembangan diagram alur untuk menunjukkan hubungan kausalitas; 3) konversi diagram alur ke dalam serangkaian persamaan struktural dan spesifikasi model pengukuran; 4) pemilihan matriks input dan teknik estimasi atas model yang dibangun; 5) penilaian identifikasi masalah; 6) evaluasi model; dan 7) interpretasi dan modifikasi model.
Tabel 1 Sebaran dan statistik relasi gender per dimensi pada keluarga nelayan

\begin{tabular}{llcc}
\hline \multirow{2}{*}{$\begin{array}{c}\text { Dimensi Relasi } \\
\text { Gender }\end{array}$} & $\begin{array}{l}\text { Suami/ } \\
\text { istri }\end{array}$ & $\begin{array}{c}\text { Suami/istri } \\
\text { dominan }\end{array}$ & $\begin{array}{c}\text { Suami/istri } \\
\text { setara } \\
\end{array}$ \\
& saja & $(60,0-79,0)$ & $(80,0-$ \\
& $(00,0-60,0$ & & $100,0)$ \\
\hline Domestik & 35,0 & 40,0 & 25,0 \\
Publik & 53,3 & 40,0 & 6,7 \\
Sosial & 10,0 & 51,7 & 38,3 \\
Kemasyarakatan & & & \\
\hline
\end{tabular}

\section{HASIL}

\section{Karakteristik Keluarga}

Usia suami dan istri berkisar antara 18-70 tahun dengan rata-rata usia suami dan istri pada keluarga nelayan adalah suami 42,3 tahun dan istri 39,8 tahun. Suami dan istri pada keluarga nelayan lebih dari setengahnya $(58,4 \%)$ berkisar antara usia 40-65 tahun. Tingkat pendidikan formal mayoritas suami dan istri pada keluarga nelayan adalah tamat $\mathrm{SD}$, dengan persentase suami dan istri sama besar $(71,7 \%)$. Adapun masih ditemukan juga 26,7 persen suami dan 16,7 persen istri tidak tamat SD. Jika dikategorikan berdasarkan lama pendidikan yang ditempuh oleh suami dan istri, maka seluruh pasangan suami dan istri $(100,0 \%)$ berpendidikan kurang dari 9 tahun. Selanjutnya, lama menikah suami istri berkisar antara 3-45 tahun dan rata-rata lama menikah keluarga adalah 20,2 tahun. Hasil penelitian menunjukkan bahwa 56,7 persen keluarga nelayan termasuk keluarga kecil dan sisanya $(43,3 \%)$ termasuk keluarga sedang dengan rata-rata jumlah anggota keluarga adalah empat orang. Rata-rata pendapatan per kapita keluarga nelayan Rp814.000,00.

\section{Relasi Gender}

Hasil penelitian menunjukkan keluarga nelayan yang melakukan relasi gender setara antara suami dan istri dengan dimensi sosial kemasyarakatan tertinggi $(38,3 \%)$. Hal tersebut tercermin dari suami dan istri sering terlibat dalam kegiatan tolong-menolong dengan keluarga besar dan tetangga $(41,7 \%)$ dan partisipasi dalam kegiatan masyarakat, misalnya acara 17 Agustus (36,7\%).

Dimensi Domestik. Hasil penelitian menunjukkan bahwa hal yang dominan dilakukan oleh suami adalah merencanakan perbaikan rumah $(55,0 \%)$ dan memperbaiki rumah ketika rusak $(50,0 \%)$. Selanjutnya, hal yang dominan dilakukan istri adalah mencuci baju $(50,0 \%)$ dan mengasuh anak $(51,7 \%)$ (Tabel 1). 
Tabel 2 Sebaran dan statistik manajemen keuangan per dimensi pada keluarga nelayan

\begin{tabular}{|c|c|c|c|}
\hline \multirow[b]{2}{*}{$\begin{array}{c}\text { Dimensi } \\
\text { Manajemen } \\
\text { Keuangan }\end{array}$} & \multicolumn{3}{|c|}{ Kategori (\%) } \\
\hline & $\begin{array}{r}\text { Rendah } \\
(00,0- \\
60,0) \\
\end{array}$ & $\begin{array}{r}\text { Sedang } \\
(60,0-79,0)\end{array}$ & $\begin{array}{l}\text { Tinggi } \\
(80,0- \\
100,0) \\
\end{array}$ \\
\hline Perencanaan & 100,0 & 0,0 & 0,0 \\
\hline Pengorganisasian & 100,0 & 0,0 & 0,0 \\
\hline Pelaksanaan & 100,0 & 0,0 & 0,0 \\
\hline Evaluasi & 100,0 & 0,0 & 0,0 \\
\hline
\end{tabular}

Dimensi Publik. Secara keseluruhan dimensi publik hampir didominasi oleh suami dikarenakan bagi keluarga nelayan, pekerjaan mencari nafkah lebih dari 40 jam per minggu $(50,0 \%)$ serta menambah jam kerja $(55,5 \%)$ dan memiliki pekerjaan lain/musiman $(58,3 \%)$ adalah pekerjaan yang dominan dilakukan oleh suami (Tabel 1).

Dimensi Sosial Kemasyarakat. Berdasarkan Tabel 1, hal yang dominan dilakukan oleh suami adalah mengikuti pertemuan RT/RW $(50,0 \%)$ dan mengikuti kegiatan agama $(58,3 \%)$, sedangkan hal yang dominan dilakukan oleh istri adalah tolong-menolong dengan keluarga besar dan tetangga $(46,7 \%)$.

\section{Tekanan Ekonomi}

Tekanan Ekonomi Objektif. Hasil penelitian menunjukkan bahwa sebagian besar keluarga nelayan $(70,0 \%)$ tidak merasa tertekan terhadap kondisi ekonomi objektif keluarga. Hal tersebut dapat dilihat dari pendapatan kepala rumah tangga di atas Rp600.000,00/bulan (93,3\%), sumber penerangan rumah yang menggunakan listrik $(91,7 \%)$, memiliki tabungan/barang yang dapat dijual dengan harga minimal Rp500.000,00 $(88,3 \%)$, bahan bakar yang digunakan keluarga adalah gas elpiji $(78,3 \%)$ dan tempat tinggal yang layak dengan ukuran lebih dari $8 m^{2}$ per orang $(51,7 \%)$. Akan tetapi masih ditemukan pula 1,7 persen keluarga nelayan yang merasa tertekan terhadap kondisi ekonomi objektif keluarga.

Tabel 3 Sebaran dan statistik strategi nafkah per dimensi pada keluarga nelayan

\begin{tabular}{lccc}
\hline \multirow{2}{*}{$\begin{array}{c}\text { Dimensi Strategi } \\
\text { Nafkah }\end{array}$} & $\begin{array}{c}\text { Rendah } \\
(00,0- \\
60,0)\end{array}$ & $\begin{array}{c}\text { Sedang } \\
(60,0- \\
79,0)\end{array}$ & $\begin{array}{c}\text { Tinggi } \\
(80,0- \\
100,0)\end{array}$ \\
\hline Rekayasa & 100,0 & 0,0 & 0,0 \\
$\begin{array}{l}\text { Sumber Nafkah } \\
\text { Pola Nafkah }\end{array}$ & 90,0 & & 0,0 \\
Ganda & 10,0 & 0,0 \\
Pola Imigrasi & 100,0 & 0,0 & 0,0 \\
\hline
\end{tabular}

Hal tersebut dikarenakan ketidakmampuan keluarga dalam memenuhi kebutuhan protein hewani dalam setiap minggunya $(66,7 \%)$, ketidakmampuan keluarga dalam menggunakan uang untuk memenuhi kebutuhan sandang keluarga $(80,0 \%)$, dan pendidikan kepala rumah tangga masih terkategori rendah (tamat SD) (83,3\%). Berdasarkan hasil penelitian secara keseluruhan menunjukkan bahwa keluarga nelayan dapat memenuhi kebutuhan minimal keluarga, seperti tempat tinggal yang layak, sumber penerangan rumah dari listrik, bahan bakar untuk memasak adalah gas elpiji, memiliki penghasilan diatas Rp600.000,00 per bulan.

Tekanan Ekonomi Subjektif. Hasil penelitian menunjukkan bahwa keluarga nelayan tidak merasa tertekan terhadap kondisi ekonomi subjektif keluarga yaitu 63,3 persen merasakan hal tersebut. Hal ini diperlihatkan dengan keluarga nelayan tidak menganggap masalah keuangan akan mengganggu urusan pekerjaan dan kehidupan sehari-hari $(51,7 \%)$ atau mengganggu hubungan keluarga dengan orang lain $(55,0 \%)$ dan keluarga merasa cukup terhadap kebutuhan pangan (makanan seharihari) dan nonpangan primer (pakaian, perumahan, dan alat kebersihan) (41,7\%). Selain itu, anak tidak kecewa jika keluarga belum mampu memenuhi keinginannya, seperti membeli mainan atau pergi liburan sehingga keluarga tidak merasa khawatir $(63,3 \%)$. Namun, enam dari sepuluh istri merasa kesulitan untuk menyisihkan tabungan dan membutuhkan bantuan keuangan untuk memenuhi kebutuhan pokok dari orang tua atau saudara. Keluarga nelayan juga merasa bahagia dengan kondisi ekonomi subjektif keluarga.

\section{Manajemen Keuangan Keluarga}

Manajemen keuangan seluruh keluarga nelayan $(100,0 \%)$ masih terkategori rendah. Hal tersebut ditunjukkan dari keluarga tidak pernah melakukan perencanaan keuangan seperti menghitung perkiraan biaya hidup dan menuliskan tujuan keuangan masa depan.

Dimensi Perencanaan. Berdasarkan Tabel 2 secara keseluruhan keluarga berada pada kategori rendah, hal tersebut ditunjukkan dengan keluarga tidak pernah menuliskan tujuan keuangan $(98,3 \%)$, tidak pernah membuat perencanaan penggunaan uang dalam satu bulan $(51,7 \%)$ dan tidak pernah menghitung perkiraan biaya hidup sehari-hari $(48,3 \%)$. 
Tabel 4 Sebaran dan statistik kualitas hidup per dimensi pada keluarga nelayan

\begin{tabular}{lccc}
\hline \multirow{2}{*}{$\begin{array}{c}\text { Kimensi Tekanan } \\
\text { Ekonomi }\end{array}$} & $\begin{array}{c}\text { Kendah } \\
(00,0- \\
60,0)\end{array}$ & $\begin{array}{c}\text { Sedang } \\
(60,0-\end{array}$ & $\begin{array}{c}\text { Tinggi } \\
(80,0-\end{array}$ \\
& & & $100,0)$ \\
\hline Kualitas Hidup & & & \\
Objektif & & & \\
$\quad$ Rumah & 63,3 & 10,0 & 26,7 \\
Standar & 98,3 & 1,7 & 0,0 \\
Kehidupan & 63,3 & 15,0 & 21,7 \\
Pendapatan & 88,3 & 10,0 & 1,7 \\
Kesehatan & 61,7 & 31,7 & 6,7 \\
Pekerjaan & 90,0 & 5,0 & 5,0 \\
$\quad$ Lingkungan & & & \\
Personal & & & \\
\hline Kualitas Hidup & & 61,7 & 0,0 \\
Subjektif & 38,3 & 33,3 & 0,0 \\
Fisik & 66,7 & 55,0 & 0,0 \\
Ekonomi & 45,0 & 100,0 & 0,0 \\
Psikologis & 0,0 & & \\
Komunikasi & &
\end{tabular}

Dimensi Pengorganisasian. Hasil penelitian menunjukkan bahwa keluarga nelayan pada penelitian ini berada pada kategori rendah, yang tercermin dari keluarga tidak pernah mencatat seluruh pendapatan $(98,3 \%)$, tidak pernah menuliskan pengeluaran keuangan $(98,3 \%)$, dan tidak pernah menetapkan standar biaya maksimal dalam pengalokasian pengeluaran (Tabel 2)

Dimensi Pelaksanaan. Hasil penelitian menunjukkan bahwa keluarga terkategori rendah dalam hal pelaksanaan manajemen keuangan. Meskipun demikian, masih terdapat keluarga yang kurang sesuai dengan yang telah dianggarkan $(68,3 \%)$ dan pernah melakukan pengeluaran dan berusaha menabung $(55,0 \%)$.

Dimensi Evaluasi. Tabel 2 memperlihatkan bahwa keluarga nelayan pada penelitian ini rendah dalam hal evaluasi keuangan. Hal tersebut tercermin dari keluarga tidak pernah mengevaluasi pengeluaran secara rutin dan menyeluruh $(73,3 \%)$ dan tidak pernah membandingkan penerimaan dan pengeluaran keluarga $(55,0 \%)$.

\section{Strategi Nafkah}

Hasil penelitian menunjukkan bahwa keluarga nelayan masih rendah dalam upaya strategi nafkah untuk meningkatkan pendapatan keluarga pada semua dimensi, yaitu rekayasa sumber nafkah $(100,0 \%)$, pola nafkah ganda $(90,0 \%)$ dan pola imigrasi $(100,0 \%)$. Seluruh dimensi strategi nafkah pada keluarga nelayan menunjukkan terkategori rendah. Hal tersebut tercermin dari kurangnya upaya keluarga untuk meragamkan sumber nafkah utama khususnya pada saat musim paceklik tiba, merasa cukup dengan jam kerja setiap harinya sehingga tidak menambah jam kerja, keterbatasan modal membuat keluarga tidak mampu menggunakan teknologi modern untuk meningkatkan produktivitas, dan masih adanya keluarga yang mencari nafkah hanya kepala rumah tangga saja.

Dimensi Rekayasa Sumber Nafkah. Kategori rekayasa sumber nafkah keluarga adalah rendah, hal tersebut tercermin dari tidak pernah menambah jam kerja $(76,7 \%)$ dan tidak pernah memperluas usaha $(53,35)$. Meskipun demikian, keluarga pernah meragamkan sumber nafkah utama $(48,3 \%)$ dan pernah meminjam modal untuk usaha $(53,3 \%)$ (Tabel 3)

Dimensi Nafkah Ganda. Tabel 3 menunjukkan terdapat 10 persen keluarga nelayan yang berada pada kategori sedang yang ditunjukkan dengan anggota keluarga selain kepala rumah tangga pernah bekerja $(71,7 \%)$ dan anggota keluarga bekerja di daerah lain $(48,3 \%)$.

Dimensi Pola Imigrasi. Berdasarkan hasil penelitian keluarga nelayan pernah melakukan pola imigrasi yaitu dua dari sepuluh keluarga yang anggota keluarganya bekerja sebagai TKW/TKI di Taiwan dan Singapura. Pola imigrasi berada pada kategori rendah (Tabel $3)$.

\section{Kualitas Hidup}

Kualitas Hidup Objektif. Kualitas hidup objektif terdiri dari enam dimensi yaitu, rumah, standar kehidupan, pendapatan, kesehatan, pekerjaan, dan lingkungan personal. Hasil penelitian menunjukkan bahwa sekitar empat dari limakeluarga nelayan $(88,3 \%)$ memiliki kualitas hidup objektif terkategori rendah, termasuk pada semua dimensi dalam kategori rendah. Keluarga nelayan merasa kesulitan mengupayakan pemenuhan kebutuhan pada dimensi standar kehidupan (98,3\%) dan lingkungan personal (90,0\%). Adapun hal tersebut diperlihatkan dengan keluarga tidak mampu membeli baju secara rutin (minimal sebulan sekali) $(98,3 \%)$, tidak makan sehari tiga kali $(83,3 \%)$, tidak mengganti peralatan rumah tangga yang rusak $(80,0 \%)$, lingkungan rumah kotor $(81,7 \%)$, dan lingkungan rumah tidak memiliki kualitas air yang baik $(76,7 \%)$. Adapun pada dimensi rumah dan pendapatan, dua dari sepuluh keluarga memiliki kualitas yang baik. 
Tabel 5 Dekomposisi efek faktor-faktor yang berpengaruh antar variabel pada keluarga nelayan

\begin{tabular}{|c|c|c|c|c|c|c|c|}
\hline \multirow{2}{*}{$\begin{array}{c}\text { Variabel } \\
\text { Laten }\end{array}$} & \multirow{2}{*}{$\begin{array}{l}\text { Total } \\
\text { Effect }\end{array}$} & \multicolumn{5}{|c|}{ Indirect Effect } & \multirow{2}{*}{$\begin{array}{l}\text { Direct } \\
\text { Effect }\end{array}$} \\
\hline & & $\mathbf{K H}$ & TE & MK & SN & $\mathbf{R G}$ & \\
\hline \multicolumn{8}{|l|}{ Kualitas } \\
\hline \multicolumn{8}{|l|}{ Hidup } \\
\hline - Relasi Gender & 0,339 & & & 0,168 & & & 0,158 \\
\hline - Manajemen Keuangan & 0,067 & & & & & & 0,067 \\
\hline - Strategi Nafkah & 0,238 & & & 0,128 & & & 0,110 \\
\hline - Tekanan Ekonomi & $-0,213^{\star}$ & & & 0,191 & 0,153 & 0,202 & $-0,759^{*}$ \\
\hline \multicolumn{8}{|l|}{ Manajamen } \\
\hline \multicolumn{8}{|l|}{ Keuangan } \\
\hline - Relasi Gender & 0,156 & & & & & & 0,156 \\
\hline - Strategi Nafkah & $0,408^{*}$ & & & & & & $0,408^{*}$ \\
\hline - Tekanan Ekonomi & $-0,168^{\star}$ & & & & 0,137 & 0,000 & $-0,305^{\star}$ \\
\hline \multicolumn{8}{|l|}{ Relasi Gender } \\
\hline - Tekanan Ekonomi & 0,091 & & & & & & 0,091 \\
\hline \multicolumn{8}{|l|}{ Strategi } \\
\hline \multicolumn{8}{|l|}{ Nafkah } \\
\hline - Relasi Gender & $0,333^{\star}$ & & & & & & $0,333^{*}$ \\
\hline - Tekanan Ekonomi & $-0,479$ & & & & & $-0,200$ & $-0,279$ \\
\hline
\end{tabular}

Hal tersebut tercermin dari kamar tidur keluarga yang terpisah dari ruangan lain $(66,7 \%)$, rumah milik sendiri $(61,7 \%)$, penghasilan bersih setiap bulan cukup untuk memenuhi kebutuhan hidup (40,0\%), dan tiga dari sepuluh keluarga memiliki tabungan. Hasil penelitian menunjukkan keluarga nelayan $(53,3 \%)$ memiliki kualitas hidup rendah secara objektif terutama dalam hal standar kehidupan, kesehatan dan lingkungan personal. Selain itu, rendahnya kualitas hidup objektif juga ditunjukkan dari rendahnya kemampuan keluarga dalam memenuhi kebutuhan sandang, pangan, kemampuan berobat secara medis, dan menjaga lingkungan di sekitar rumah serta enam dari sepuluh keluarga memiliki rumah yang cukup layak untuk dihuni.

Kualitas Hidup Subjektif. Kualitas hidup subjektif terdiri dari empat dimensi yaitu fisik, ekonomi dan psikologis. Keluarga nelayan merasa cukup berkualitas pada dimensi fisik dan komunikasi. Hal ini diperlihatkan dengan adanya hubungan komunikasi dengan suami, anak, orang tua, mertua dan keluarga besar; dan merasa puas dalam hal kesehatan suami $(90,0 \%)$, kesehatan anak $(90,0 \%)$, pembagian peran antar suami dan istri $(86,7 \%)$, hubungan komunikasi dengan anak, suami, orang tua, mertua dan keluarga besar (100,0\%). Adapun pada dimensi lainnya, keluarga merasa belum puas dengan kualitas hidup subjektif, terutama pada dimensi ekonomi dan psikologis. Hasil penelitian menunjukkan bahwa enam dari sepuluh keluarga merasa tidak puas terhadap keadaan keuangan (pendapatan, tabungan dan aset/materi) keluarga, dan juga empat dari sepuluh keluarga merasa tidak puas dengan pakaian, alat transportasi dan media komunikasi keluarga. Selain itu, empat dari sepuluh keluarga merasa tidak puas dengan kondisi spiritual dan kebersihan rumah. Keluarga nelayan merasa hidupnya kurang berkualitas terutama dalam hal kondisi keuangan. Walaupun demikian, keluarga tetap merasa bahagia dengan komunikasi yang terjalin antar anggota keluarga sebanyak enam dari sepuluh. Keluarga merasa senang dengan kepemilikan rumah sendiri dan kemampuan untuk memenuhi kebutuhan pangan harian.

\section{Faktor-Faktor yang Memengaruhi Kualitas Hidup}

Berdasarkan model empirik yang diajukan dalam penelitian ini dapat dilakukan pengujian terhadap hipotesis melalui pengujian koefisien jalur pada model persamaan struktural pada Gambar 1. Tabel 5 menjelaskan tentang hasil estimasi model SEM. Pengaruh antarvariabel pada keluarga nelayan yang berpengaruh langsung dan signifikan yaitu pengaruh tekanan ekonomi terhadap manajemen keuangan, pengaruh strategi nafkah terhadap manajemen keuangan, pengaruh relasi gender terhadap strategi nafkah dan pengaruh tekanan ekonomi terhadap kualitas hidup. 


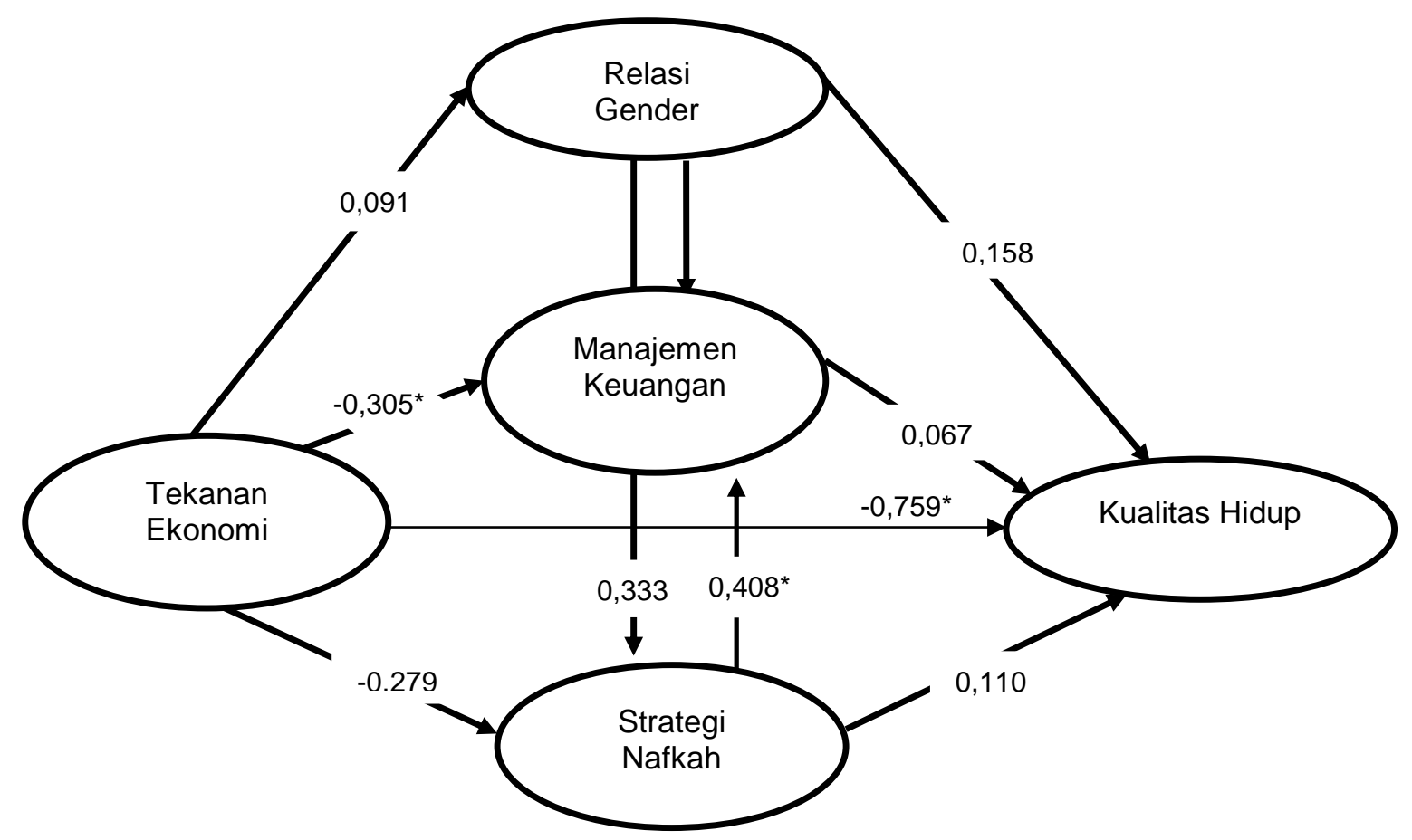

Gambar 1 Hasil Model sesuai dengan Rancangan Penelitian

Hasil analisis pengujian hipotesis model variabel-variabel terhadap kualitas hidup pada keluarga nelayan menunjukkan angka $R$ Square sebesar 0,532 yang berarti model tersebut menjelaskan 53,2 persen model variabel-variabel memengaruhi kualitas hidup dan sisanya 46,8 persen dipengaruhi variabel lain di luar penelitian ini. Hasil penelitian menunjukkan tekanan ekonomi ( $\beta=-$ $0,305 ; t>1,96)$ berpengaruh langsung negatif terhadap manajemen keuangan, strategi nafkah $\quad(\beta=0,408 ; t>1,96) \quad$ berpengaruh langsung positif terhadap manajemen keuangan, relasi gender $(\beta=0,333 ; t>1,96)$ berpengaruh langsung positif terhadap strategi nafkah, tekanan ekonomi $(\beta=-0,759 ; t>1,96)$ berpengaruh langsung negatif terhadap kualitas hidup.

\section{PEMBAHASAN}

Pendekatan teori struktural fungsional digunakan dalam penelitian ini yang memandang bahwa pembagian peran dan fungsi secara seimbang merupakan landasan keluarga dalam menjalankan relasi gender, manajemen keuangan, dan strategi nafkah untuk mencapai kualitas hidup. Permasalahan yang dihadapi oleh sebagian besar keluarga nelayan dalam penelitian ini adalah tingkat pendidikan pasangan suami dan istri yang rendah (tamat SD). Menurut Herawati et al. (2011) tingkat pendidikan yang rendah pada pasangan suami dan istri akan berimplikasi pada jenis pekerjaan yang dimiliki. Jenis pekerjaan yang dimiliki oleh suami adalah buruh nelayan, sementara sebagian besar istri tidak bekerja (ibu rumah tangga). Menurut Yadollahi et al. (2009) tingkat pendidikan seseorang merupakan determinan penting yang menentukan pekerjaan seseorang. Hasil penelitian Raviv, Gefen, dan Fink (2009) menyatakan bahwa tingkat pendidikan seseorang akan menentukan tingkat upah dan status ekonomi keluarga. Adapun pekerjaan yang dimiliki keluarga nelayan memiliki besaran pendapatan yang tidak tetap. Kondisi ini mengakibatkan lebih dari setengah responden memiliki kebiasaan berhutang untuk memenuhi kebutuhan hidupnya. Hasil ini sejalan dengan penelitian Herawati et al. (2011) yang menemukan bahwa berhutang adalah salah satu tindakan yang dilakukan keluarga untuk memenuhi kebutuhan keluarga pada masa sulit. Permasalahan lain yang dihadapi oleh keluarga nelayan adalah nilainilai yang dianut dalam menjalani kehidupan sehari-hari didominasi oleh sikap pasrah dan sabar. Nilai tersebut mencerminkan kondisi keluarga yang statis sehingga usaha untuk mendapatkan kehidupan yang lebih baik relatif rendah.

Tekanan ekonomi berpengaruh secara negatif dan signifikan terhadap manajemen keuangan 
pada keluarga nelayan. Semakin keluarga tertekan secara ekonomi maka kualitas manajemen keuangan keluarga akan menurun. Hasil penelitian ini sesuai dengan penelitian sebelumnya yang dilakukan oleh Fofana (2009); Firdaus dan Sunarti (2009) yang juga menemukan bahwa tekanan ekonomi berpengaruh terhadap manajemen keuangan. Menurut Herawati et al. (2011), beberapa faktor yang memengaruhi tekanan ekonomi adalah pendidikan rendah. Pendidikan rendah berpengaruh terhadap kemampuan manajemen istri terutama dalam hal manajemen keuangan sehingga tingginya tekanan ekonomi keluarga nelayan dan rendahnya pendidikan yang diterima istri akan menurunkan manajemen keuangan keluarga. Menurut Okech (2012), manajemen keuangan yang dilakukan keluarga memberikan efek positif bagi ketahanan keluarga terutama dalam menurunkan tekanan ekonomi. Menurut Skogrand et al. (2011), untuk dapat memperkecil tekanan ekonomi yang dihadapi keluarga maka diperlukan manajemen keuangan yang baik.

Strategi nafkah berpengaruh secara positif dan signifikan terhadap manajemen keuangan pada keluarga nelayan. Semakin baik strategi nafkah maka manajemen keuangan keluarga akan meningkat. Hasil penelitian ini menunjukkan strategi nafkah dan manajemen keuangan terkategori rendah. Hal tersebut tercermin dari keluarga yang tidak memperluas usaha, tidak memperluas lahan dan tidak menambah tenaga kerja, keluarga tidak pernah menuliskan tujuan keuangan, tidak mencatat seluruh pendapatan dan tidak menuliskan pengeluaran keluarga. Oleh karenanya, penting bagi keluarga untuk meningkatkan strategi nafkah. Hasil sejalan dengan penelitian sebelumnya yang dilakukan oleh Hakim (2014) bahwa strategi nafkah yang baik akan meningkatkan manajemen keuangan. Menurut Tulak, Dharmawan, dan Juanda (2009); Kalinda dan Lanyingtuo (2014), strategi nafkah merupakan upaya keluarga untuk mengurangi tekanan ekonomi dan menambah pendapatan keluarga.

Relasi gender berpengaruh secara positif dan signifikan terhadap strategi nafkah pada keluarga petani dan keluarga nelayan. Semakin responsif relasi gender dalam keluarga maka strategi nafkah akan meningkat. Relasi gender pada keluarga nelayan berada pada kategori dominan salah satu pihak, yang artinya suami dan istri saling bekerja sama, namun masih didominasi oleh salah satunya. Menurut Nugraheni (2012), relasi gender berpengaruh terhadap strategi nafkah, kebutuhan hidup dasar yang tidak terpenuhi mendorong istri berusaha memenuhi kekurangan tersebut dengan bekerja yang kemudian menjadikan istri memiliki peran ganda. Menurut Widiyanto, Suwarto, dan Retno (2010), istri yang terlibat dalam pemenuhan kebutuhan keluarga merupakan salah satu cara dari strategi nafkah yang memanfaatkan modal manusia di dalam keluarga yaitu pola nafkah ganda untuk menjaga hubungan harmonis dalam keluarga dibutuhkan relasi gender yang responsif.

Tekanan ekonomi berpengaruh secara negatif dan signifikan terhadap kualitas hidup pada keluarga nelayan. Semakin tertekan keluarga secara ekonomi maka kualitas hidup keluarga akan menurun. Ditinjau dari aspek kualitas hidup lebih dari setengah kualitas hidup objektif dan subjektif keluarga petani terkategori rendah. Hasil penelitian ini sesuai penelitian sebelumnya yang dilakukan oleh Simanjuntak, Puspitawati, dan Djamaludin (2010) yang menemukan bahwa tekanan ekonomi berhubungan negatif nyata dengan kualitas hidup. Semakin rendah tekanan ekonomi semakin tinggi kualitas hidup yang dirasakan keluarga. Menurut Firdaus dan Sunarti (2009), tekanan ekonomi yang dirasakan keluarga akan membentuk persepsi keluarga terhadap aspek-aspek yang terkait dengan kualitas hidup keluarga. Keluarga yang merasakan tekanan ekonomi akan melakukan mekanisme tertentu dengan memanfaatkan sumber daya yang ada untuk mengurangi tekanan tersebut hingga dapat terwujudnya kualitas hidup yang lebih baik (kesejahteraan keluarga). Menurut Raharjo, Puspitawati, dan Krisnatuti (2015), tingginya tekanan ekonomi yang dirasakan keluarga akan menurunkan tingkat kesejahteraan.

\section{SIMPULAN DAN SARAN}

Usia keluarga nelayan berada pada usia produktif (22-65 tahun) sehingga potensi untuk melakukan aktivitas ekonomi relatif tinggi. Tingkat pendidikan formal yang pernah ditempuh mayoritas suami dan istri pada keluarga petani tergolong rendah (tamat SD). Rata-rata pendapatan per kapita keluarga nelayan sebesar Rp814.000,00 berada di atas garis kemiskinan Kabupaten Subang yaitu sebesar Rp303.583,00 (BPS Jawa Barat 2016). Rata-rata besar keluarga nelayan lebih dari setengahnya terkategori keluarga kecil ( $\leq 4$ orang). Keluarga nelayan berada pada kategori relasi gender suami atau istri dominan, yaitu suami dan istri saling 
berdiskusi, namun pada pelaksanaanya didominasi oleh salah satu pihak. Tekanan ekonomi yang dirasakan keluarga nelayan tergolong rendah. Keluarga nelayan belum melaksanakan manajemen keuangan keluarga dengan baik. Strategi nafkah keluarga nelayan pada semua dimensi masih terkategori rendah. Kualitas hidup keluarga masih rendah. Hasil penelitian menunjukkan bahwa tekanan ekonomi berpengaruh nyata terhadap manajemen keuangan, strategi nafkah berpengaruh nyata terhadap manajemen keuangan, relasi gender berpengaruh nyata terhadap strategi nafkah, dan tekanan ekonomi berpengaruh nyata terhadap kualitas hidup.

Berdasarkan hasil yang diperoleh dari penelitian ini, saran yang dapat diberikan adalah sebagai berikut: (1) keluarga petani sebaiknya lebih meningkatkan manajemen keuangan dan strategi nafkah keluarga, dengan bantuan penyuluhan dari LSM atau perguruan tinggi dan meningkatkan pengetahuan dan praktik manajemen keuangan agar keluarga lebih berkualitas; (2) pemerintah atau instansi terkait diharapkan dapat menyediakan program untuk meningkatkan kualitas hidup, seperti meningkatkan fungsi koperasi dan memberikan pelatihan pengolahan pangan lokal. Selain itu, penelitian selanjutnya perlu dilakukan dengan membandingkan beragam pola relasi gender, tekanan ekonomi, manajemen keuangan, strategi nafkah, dan kualitas hidup yang diukur secara bersama pada berbagai macam tipologi pesisir yang sangat beragam di wilayah Indonesia. Hal ini akan dapat memberikan keragaman empiris tentang kehidupan keluarga masyarakat pesisir di Indonesia.

\section{DAFTAR PUSTAKA}

[BPS] Badan Pusat Statistik. 2013. Jumlah Penduduk Miskin. Jakarta (ID): Badan Pusat Statistik.

Chin. (2000). Partial Least Squares For Researcher: An Overview and Presentation of Recent UsingThe PLS Approach: University of Houston. Texas.

Dharmawan, A.H. (2007). Sistem penghidupan dan nafkah pedesaan: pandangan sosiologi nafkah (livelihood sociology) mahzab Barat dan mahzab Bogor. Sodality: Jurnal Transdisiplin Sosiologi, Komunikasi, dan Ekologi Manusia. 01(2):169-192. ISSN: 1978-4333.
Durband, D., Britt, S., \& Grable, J. (2010). Personal and Family Finance in the Marriage and Family Therapy Domain. The Journal of Financial Therapy, 1 (1), 7-21,DOI: 10.4148/jft.v1i1.242.

Fofana. (2009). A socio-economic sustainability assessment of livelihoods from scrap metal collection in Freetown, Sierra Leone (Tesis). Lund University International, Lund, Swedia.

Firdaus., \& Sunarti, E. (2009). Hubungan antara tekanan ekonomi, manajemen keuangan, dan mekanisme koping dengan kesejahteraan keluarga wanita pemetik teh. Jurnal IImu Keluarga dan Konsumen, 2(1), 21-31. DOI: http://dx.doi.org/10.24156/jikk.2009.2.1 21 .

Fitzsimmons, V.S., Hira, T.K., Bauer, J.W., \& Hafstrom, J.L. (1993). Financial management: development of scales. Journal of Family and Economic Issues. 14(3), 257-274. ISSN: 1058-0476.

Grable, J.E., Park, J.Y., \& Joo, S.H. (2009). Explaining financial management behavior for Koreans living in the United States. Journal of Consumer Affairs. 43(1):80-105. DOI: http://doi.org/10.1111/j.17456606.2008.01128.x.

Hakim, F.A. (2014). Manajemen keuangan dan keputusan keuangan istri pada keluarga dengan suami istri bekerja. Jurnal IImu Keluarga dan Konsumen 7(3), 1-9.

DOl: http://dx.doi.org/10.24156/jikk.2014.7.3 .174

Herawati, T., Ginting., Asngari., Susanto., \& Puspitawati, H. (2011). Ketahanan pangan keluarga peserta program pemberdayaan masyarakat di pedesaan. Jurnal Gizi dan Pangan, 2011, 6(3), 208-216. DOI: http://dx.doi.org/10.25182/jgp.2011.6.3.2 08-216.

Hilton., \& Devall. (1997). The Family economic strain scale: development and evaluation of the instrument with single and two parents. Journal of Family and Economic Issues. 18(3), 248-271. ISSN: 1058-0476.

Husin, S. (2009). Analisis faktor-faktor yang mempengaruhi produktivitas usaha tani 
dan pengaruhnya terhadap kepuasan petani (Tesis). Universitas Indonesia, Jakarta, Indonesia.

Irzalinda, V, Puspitawati, H, Muflikhati, I. (2014). Aktivitas bersama orang tuaanak dan perlindungan anak meningkatkan kesejahteraan subjektif anak. Jurnal IImu Keluarga dan Konsumen, 7(1)40-47. DOI: http://dx.doi.org/10.24156/jgp.2014.7.1.4 0 .

Iskandar, A. (2008). Analisis praktik manajemen sumberdaya keluarga dan dampaknya terhadap kesejahteraan keluarga di Kabupaten dan Kota Bogor. Jurnal Transdisiplin Sosiologis, Komunikasi, dan Ekologi Manusia. 2(1),81-98. ISSN: 1978-4333.

Khizindar, T.M. (2009). Quality of life in developing countries: An empirical investigation. Journal of American Academy of Business. 14(2),162-170. ISSN: 1540-7780.

Kumari, K.K. (2011). Marital adjustment and family resource management of working women among different income groups. International Referred Research Journal. 3(27),37-39. ISSN: 2278-4497.

Krzaklewska, E. (2014). Measurement of gender equality analyzing dimensions, embracing areas, considering contexts.. Working paper 1(2) "Gender Equality and Quality of Life-State of Art Report".

Kalinda, T., \& Lanyingtuo, A. (2014). Livelihood strategies, shocks and coping mechanisms among rural households in southern zambia. Journal of Social Sciences. 6(4): 120-133. ISSN: 20760760.

Kusumo., Sunarti, E., \& Pranadji. (2008). Analisis peran gender serta hubungannya dengan kesejahteraan keluarga petani padi dan hortikultura di daerah pinggiran perkotaan. Media Gizi dan Keluarga 32(2): 52-64. ISSN: 02169363.

Latan, H. (2013). Model Persamaan Struktural Teori dan Implementasi AMOS 21.0. Bandung: Alfabeta.

Lawton, P.W. (2001). Quality of life and the end of life. Di dalam : Birren JE dan Schaie KW, editor. London (GB). Academic Pr.

Mudey, A., Ambekar, S., Goyal, R., Agarekar, S., \& Wagh, V. (2011). Assessment of quality of life among rural and urban elderly population of Wardha District, Maharashtra, India. Ethno Med, 5(2), 8993. DOI: https://doi.org/10.1080/09735070.2011.1 1886394.

Muflikhati, I., Hartoyo., Sumarwan, U., Fahrudin, A., \& Puspitawati, H. (2010). Kondisi sosial ekonomi dan tingkat kesejahteraan keluarga: kasus di wilayah pesisir Jawa Barat. Jurnal IImu Keluarga dan Konsumen, 3(1)1-10, DOI: http://dx.doi.org/10.24156/jikk.2010.3.1.1

Nugraheni, W. (2012). Peran dan potensi wanita dalam pemenuhan kebutuhan ekonomi keluarga nelayan. Journal of Educational Social Studies. 1(2): 104111. P-ISSN: 2252-6390, E-ISSN: 2502-4442.

Netuveli, G., \& Blane, D. (2008). Quality of life in older ages. British Medical Journal. 85,113-126. ISSN: 0007-1420.

Okech. (2012). Effect of economic pressure on resilience and strengths of indivisuals living in extreme poverty. Journal of Poverty, 16,429-446. ISSN : 1087-5549.

Park, C.M., \& Shin, D.C. (2005). Perceptions of life quality among the Korean mass public. Unraveling their dynamics and standards. E-jounal of Social Indicators Research. Vol 7(3), 1-30. ISSN: 0303-8300.

Puspitawati, H. (2009). Pengaruh nilai ekonomi pekerjaan ibu rumah tangga terhadap kesejahteraan keluarga subjektif. Jurnal IImu Keluarga dan Konsumen, 2(1),1120.

DOI: http://dx.doi.org/10.24156/jikk.2009.2.1.1 1.

(2012). Gender dan Keluarga: Konsep dan Realita di Indonesia. Bogor: IPB Press.

Raharjo, I.T., Puspitawati, H., Krisnatuti, D. (2015). Tekanan ekonomi, manajemen keuangan, dan kesejahteraan pada keluarga muda. Jurnal IImu Keluarga dan Konsumen, 8(1),38-48. DOI: http://dx.doi.org/10.24156/jikk.2015.8.1.3 8.

Robila., \& Krishnakumar. (2005). Effects of economic pressure on marital conflict in Romania. Journal of Family Psychology, 19(2), 246-251. ISSN: 0893-3200. 
Rodhiyah. (2012). Manajemen keuangan keluarga guna menuju keluarga sejahtera. Topik Utama: 28-33. ISSN: 0126-0731

Raviv., Gefen., \& Fink. (2009). The personal service gap: Factors affecting adolescents willingness to seek help. Journal of Adolescents,32(3), 483-499. ISSN: 0140-1971.

Simanjuntak, M., Puspitawati, H., Djamaludin, M. (2010). Karakteristik demografi, sosial, dan ekonomi keluarga penerima Program Keluarga Harapan (PKH). Jurnal IImu Keluarga dan Konsumen 3(2), 101-113. DOI: http://dx.doi.org/10.24156/jikk.2010.3.2.1 01

Sabarella., Komalasari, W., Respati, E., Noviati., Wahyuningsih, S., Ningrum, M.H., Sehusman. (2014). Analisis Kesejahteraan Petani. Jakarta: Pusat Data dan Sistem Informasi Pertanian Kementan.

Satria, A. (2009). Pesisir dan Laut untuk Rakyat. Bogor : IPB Press.

Muflikhati, I., Fatchiya, A., Kinseng, R., Oktariza, W., Herawati, T., Purnomo, S., Mulyanto, S., Arifianto, R. (2015). Analisis Kesejahteraan Rumah Tangga Usaha Perikanan. Jakarta : BPS.

Scoones, I. (1998). Sustainable rural livelihoods: a framework for analysis. IDS Working Paper 72, 1-23.

Sunarti, E., Tati., Atat, S.N., Noorhaisma., \& Lembayung, D.P. (2005). Pengaruh tekanan ekonomi keluarga, dukungan sosial, kualitas perkawinan, pengasuhan dan kecerdasan emosi anak terhadap prestasi belajar anak. Media Gizi dan Keluarga, 29 (1), 3440. ISSN 02116-9363.

Kholifah, I., Vidiastuti, F., Kharisma, N., Rochimah, N., \& Herawati, T. (2013). Family vulnerability, family resource management, and family strength of aging family members. Paper presented at 5th International Work and Family Conference, University of Sydney, July 17-19.

Soesilo. (2007). Penyebab kemiskinan masyarakat tani (Studi Di Dusun Ngebrong, Desa Tawangsari, Kecamatan Pujon, Kabupaten Malang). Journal of Indonesian
Applied Economics,1 (1), 57-67. PISSN: 1907-7947, e-ISSN: 2541-5395.

Skogrand, L., Johnson, A., Horrocks, A., \& DeFrain, J. (2011). Financial management practices of couples with great marriages. Journal of Family Economic, 32(1), 27-35. ISSN: 15733475

Sugiharto., Hartoyo., \& Muflikhati, I. (2016). Strategi nafkah, dan kesejahteraan keluarga pada keluarga petani tadah hujan. Jurnal Ilmu Keluarga dan Konsumen, 9(1),32-42. DOI: http://dx.doi.org/10.24156/jikk.2016.9.1 .33

Tulak, P.P., Dharmawan, A.H., \& Juanda, B. (2009). Stuktur nafkah rumah tangga petani transmigran: studi sosioekonomi di tiga kampung di Distrik Masni, Kabupaten Manokwari. Jurnal Transdisiplin Sosiologi, Komunikasi, dan Ekologi Manusia. 3(2), 203-220. ISSN: 1978-4333.

Widiyanto., Suwarto., \& Retno, S. (2010). Dinamika Nafkah Rumah Tangga Petani Pedesaan dengan Pendekatan Sustainable Livelihod Approach (SLA): Kasus Petani Tembakau di Lereng Gunung Merapi-Merbabu, Propinsi Jawa Tengah. Jurnal Agritext, 28, 8088. ISSN: 0854-8382.

Widodo, S. (2011). Strategi nafkah berkelanjutan bagi rumah tangga miskin di daerah pesisir. Jurnal Makara, Sosial Humaniora, 15(1), 1020. ISSN: 1693-6701.

Yadollahi, M., Hj Paim, L., Othman, M., Suandi, T. (2009). Factors affecting family status. European Journal of Scientific Research. 37 (1),.99-109. ISSN: 2319-7064.

Yohnson. (2004). Peran universitas di Surabaya dalam meningkatkan jumlah keluarga mapan di Surabaya (seri penelitian keuangan keluarga). Jurnal Manajemen dan Kewirausahaan 6(1): 54-71. ISSN: 1411-1438, e-ISSN: 23388234.

Zuliany. 2013. Peran Istri dalam Pengelolaan Sumber Daya Keluarga dan Kesejahteraan Subyektif Keluarga pada Sistem Matrilineal. (Skripsi). Institut Pertanian Bogor, Bogor, Indonesia 